\title{
ENGLISH TEACHERS' VOICES ON COMMUNICATIVE LANGUAGE TEACHING FOR READING IN INDONESIAN RURAL CLASSROOMS
}

\author{
Martin Kustati \\ Imam Bonjol State Islamic University, Indonesia \\ E-mail: martinkustati@yahoo.com \\ Yunisrina Qismullah Yusuf \\ Syiah Kuala University, Indonesia \\ Email: yunisrina.q.yusuf@unsyiah.ac.id \\ Nooreiny Maarof \\ National University of Malaysia, Malaysia \\ E-mail: nooreiny@ukm.edu.my
}

\begin{abstract}
The aim of this research was to find out whether English teachers teaching in rural areas in Indonesia are incorporating the Communicative Language Teaching (CLT) approach in their reading classes. The mixed research design included questionnaires, observations and interviews. A questionnaire was administered to 144 teachers in 68 rural high schools in Padang, West Sumatra. Out of these teachers, eight were chosen to be interviewed, and observations were conducted in their classes. Findings of the questionnaire showed that English teachers'perceptions and attitudes are generally positive towards CLT in teaching reading. However, the results from observations and interviews with the teachers indicated that a majority of teachers still implemented the traditional (teacher-centred) approach in teaching reading compared to the student-centred approach as suggested by CLT. The preferred choice of teaching methods in teaching reading was influenced by several factors; namely, the students'low proficiency level, their low degree of self-confidence and motivation, large class sizes, limited teaching schedule, and the teachers' insufficient knowledge on CLT implementation. Finally, this research suggests that if Indonesia expects its policy of learning reform to be successful, intensive and consistent teacher development must be well-organized, and sufficient resources must be allocated so that all schools, especially those in rural areas, can meet the objectives.
\end{abstract}

Keywords: communicative language teaching, English as a foreign language, reading, teachers'voices, rural areas.

\section{Introduction}

Jubani, Lama and Gjokutaj (2012) define reading as a basic life skill which becomes a cornerstone for success at school and life. In teaching English, the main purpose of reading in English as a Foreign Language (EFL) classes is to improve comprehension. However, in practice, for teachers in West Sumatra, Indonesia, the focus in English reading activities has often been on pronunciation of words without understanding their meaning (Kustati, 2013). Kromidha and Tabaku (2011) noted that foreign language teachers today are required to teach communicative language, and this demands them to utilize active teaching and learning strate- 
Martin KUSTATI, Yunisrina Qismullah YUSUF, Nooreiny MAAROF. English teachers' voices on communicative language teaching for reading in Indonesian rural classrooms

\section{PROBLEMS \\ OF EDUCATION \\ IN THE $21^{\text {st }}$ CENTURY Vol. 76, No. 5, 2018 \\ 650}

gies. In the Communicative Language Teaching (CLT) approach, teachers prepare communication activities to get students to use English actively in class. Zangoei and Derakhshan (2014) explain that students' ability to learn the target language is determined by their competency in communication and language use in real life situations. Therefore, students learning English should be able to communicate and interact using this language. In reading classes language use can be encouraged by involving students in activities such as role-plays, games, problemsolving tasks, and peer and group activities. Through these activities, students are expected to actively express and share ideas. Along the way, this should help them increase their vocabulary, broaden their knowledge, be more interested to read, and also become competent users of English. Working in pairs or groups is a way to improve the students' individual learning in the classroom (Achmad \& Yusuf, 2014; Yusuf, Natsir, \& Hanum, 2015). In reading, specifically, students can become reflective readers when they engage and communicate in groups (Chen, Chern, \& Wu, 2016).

Recent research has focused on three advantages of CLT in teaching reading. First, students are encouraged to be active learners because the techniques employed in teaching reading via CLT are student-centred (Brandl, 2002; Jacobs \& Farrell, 2003; Richards \& Rodgers, 2000; Rodgers, 2001). Second, students' understanding of the language is enhanced because the focus of teaching activities is on meaning and function of language (Brown, 2002; Hinkel, 2006; Hu, 2002). Third, the implementation of CLT enables students to become highly motivated by giving them a sense of achievement when they understand and are involved in reading through the use of task-based activities, pair and group activities, and peer correction (Berardo, 2006; Hampel \& Hauck, 2004; Richards, 2005). Kustati's (2013) research in particularly has advocated for the advantages of CLT approaches in EFL countries, such as Indonesia. Moreover, since the 1960s, CLT has become a standard practice in Anglo-American ESL classes (Hamp-Lyons, 2000). According to $\mathrm{Hu}$ (2002), thus far CLT is regarded as the most popular and influential approach in ESL and EFL settings.

However, the implementation of CLT in teaching reading has not been without problems, especially in the Indonesian context (Musthafa, 2001; Nur, 2003). Four factors have been identified that contribute to this situation. First, EFL teachers' misunderstandings of the CLT principles have led to ineffective implementation. For example, Thompson (1996) argues that a majority of teachers assume the approach to be about teaching speaking only wither in pair work or performing role plays, in which they expect too much from students and not teaching grammar at all. Meanwhile, some teachers perceive grammar accuracy as more important than speaking fluency. As a result, they tend to opt for using other traditional methods over CLT due to a preference for grammar accuracy over speaking fluency (Koosha \& Yakhabi, 2012). Second, according to Ansarey (2012), large classroom sizes of 40 to 50 students limit the range of activities available to teachers. It is difficult for the teachers to monitor this many students particularly for group activities. Although small groups and whole group discussions and pair work activities might resolve some large class problems, it is still difficult for a single teacher to be handling several groups or pairs of students in a class. Third, teachers are more concerned about completing the national syllabus to prepare students for the national examination (Djiwandono, 2015; Firman \& Tola, 2008; Huda, 1997; Musthafa, 2001). This pressurized them to teach all English language rules to enable the students to sit for the standardized examinations. Thus, communicative activities are thought to be a waste of time. Fourth, the lack of information on the principles of CLT reduced the teachers' ability to implement this new approach, especially those in rural areas. Insufficient training includes the absence of workshops, research, and seminars on CLT in these areas (Kustati, 2013). Teachers have minimal and usually fragmented understanding about CLT that make it difficult for them to leave the security of the traditional methods and take the risk of trying new, unfamiliar methods. It is also demanding for them to use the CLT approach with limited knowledge of the theories and practices. 


\section{Problem of Research}

\begin{tabular}{l} 
PROBLEMS \\
OF EDUCATION \\
IN THE 21 $1^{\text {st }}$ CENTURY \\
Vol. 76, No. 5, 2018 \\
\hline 651
\end{tabular}

The CLT approach has a resilient place in the Indonesian school curriculum. This is evident in the production of English language teaching textbooks for high schools which incorporate the principles of the CLT approach. The new textbooks have been designed in such a way that they encourage students to use English for interaction in daily communication. It is in contrast to the traditional textbooks that emphasized on a great deal of drill exercises or structured grammar-based materials. But then again, despite the availability of communicationbased textbooks and the inclusion of CLT, most teachers in Indonesia still favour the traditional grammar translation teaching method. Lewis (1996) provides evidence in his research of 320 tertiary level Indonesian students, where it was found that a majority of the students were silent during reading class. They infrequently participated in the pronunciation drills, and merely answered comprehension questions on reading or grammar exercises. Class time was spent on copying answers from the blackboard and translating texts and vocabulary words from English to Indonesian. The research also reported that most Indonesian students spent their learning time studying the English textbooks produced by the government.

\section{Research Focus}

In relation to the CLT approach in teaching reading, past studies found that many reading classes in Indonesia primarily focus on getting the reading tasks done without much interaction, either between the teachers and the students or among the students. Studies on Indonesian EFL students have shown that reading is still a struggle to them, regardless of their levels of education (e.g. secondary or tertiary levels) (Ardianti \& Mauludin, 2017; Erdiana, Kasim, \& Juwita, 2017; Gani, Yusuf, \& Susiani, 2016; Yusuf, Fajrina, \& Sari, 2016; Yusuf, Nasir, \& Rohiman, 2018). Huda (1997) and Musthafa (2001) in their research of Indonesian teachers and students find that teachers often spent their time in classes presenting the reading passages, asking students to read, and waiting for the students to complete their reading task. It was observed that students passively received the instructions and occupied most of their class time quietly reading texts. When the reading sessions were over, teachers asked several questions to check students' understanding. It was also witnessed that only a few students could cope with the tasks, whereas many others were lost. Only some exceptional students were able to read and do the tasks without guidance from the teachers. There were insufficient focuses or less discussion on comprehension activities. In other words, it suggested that teachers in Indonesia do not implement the teaching of reading as advocated in the CLT approach.

Furthermore, based on the researchers' preliminary observation, these situations were evident in the schools situated in the rural areas in Padang, West Sumatra, Indonesia. Hence, since the CLT approach is part of the Indonesian school curriculum, it was deemed crucial to research on its implementation in the schools in those rural areas. Due to the concerns posed previously in this paper, the researchers chose to examine the English teachers' views on the CLT approach, which included their background knowledge in teaching reading, approaches or methods in teaching reading, familiarity with the CLT approach, implementation of the CLT approach in teaching reading, evaluation on students' performance and perceptions in teaching reading.

\section{Methodology of Research}

\section{General Background}

A mixed research design was employed in conducting this research. This design is a type of research that combines qualitative and quantitative methods in a single study (Creswell, 2015; Johnson \& Onwuegbuzie, 2004). Data were taken in the year 2017 from English teachers 
Martin KUSTATI, Yunisrina Qismullah YUSUF, Nooreiny MAAROF. English teachers' voices on communicative language teaching for reading in Indonesian rural classrooms

IN THE $21^{\text {st }}$ CENTURY Vol. 76, No. 5, 2018

652

at different schools in the rural areas in Padang, West Sumatra, Indonesia. These were done through questionnaires, observations and interviews with the participants. This research involved four districts of the rural areas that represent the four zones of West Sumatra province. The districts are Tanah Datar, Pesisir Selatan, Agam, and Solok. There are 16 schools in Tanah Datar, 19 schools in Pesisir Selatan, 19 schools in Agam, and 14 schools in Solok, making a total of 68 schools.

\section{Sample}

A number of 144 English teachers who represented each school from the four districts in different rural areas in Padang were identified through the cluster sampling method. Prior to filling in the questionnaire of this research, consent was received from each teacher participant by having them fill out a consent form. The consent included information on the research, their bio data, and ethical and confidentiality approval. Furthermore, random purposive sampling was employed to select the teachers for semi-structured in-depth interviews and classroom observations. The exact number of in-depth interview participants was only decided when adequate information was attained and when data saturation occurred (Kvale, 1996; Neuman, 2000). Finally, eight teachers from different areas were selected to be observed and interviewed. These teachers were selected based on their consent, availability and those who could provide the insight and articulateness needed to attain the desired richness of data (Gay \& Airasian, 2000). Specifically, the criteria set for these teachers are: (i) must have at least 10 years of English language teaching experience in rural senior high schools, and (ii) should be TEFL (Teaching English as Foreign Language) trained (teachers who graduated from IKIP or Institut Keguruan dan Ilmu Pendidikan [Institute of Teacher Training and Education]). These criteria are important to ensure that they are familiar with the EFL classroom atmosphere and with the CLT approach in teaching reading.

\section{Data Generation Methods and Instruments}

The instruments employed in this research were questionnaires, observations and interviews. The questionnaire was written in both English and Indonesian, and the teacher participants could choose the language in which they could provide better detailed appropriate responses. The questionnaire consisted of six categories (categories A to F). The variables of each category are shown in Table 1 below. It was distributed by the first researcher of this paper to the teachers through email. The teachers were given one week to complete the questionnaire and to return it to the first researcher.

Table 1. Variables in the teachers' questionnaire.

\begin{tabular}{ll}
\hline Category & Variable \\
\hline A & Background knowledge in teaching reading \\
B & Approaches or methods in teaching reading \\
C & Student-centred method \\
D & Teacher-centred methods \\
E & Familiarity with the CLT approach \\
F & Implementation of the CLT approach in teaching reading \\
& Evaluation on students' performance \\
& Perceptions in teaching reading \\
\hline
\end{tabular}


Observations enabled the researchers to focus on a limited number of specific behaviours

\author{
PROBLEMS \\ OF EDUCATION \\ IN THE $21^{\text {st }}$ CENTURY \\ Vol. 76, No. 5, 2018
}

(Jackson, 2010). Teacher observations were conducted in each classroom of the eight teachers selected for interviews and observations. The purpose of this was to investigate how CLT was implemented by the English teachers in teaching reading. The type of observation checklist used in this research was an action checklist. The action checklist was adopted and modified from Brown (1994). It was divided into five parts: preparation, presentation, execution or methods, personal characteristics, and teachers or students' interaction. It was used to record whether specific behaviours were present or absent during the observation. The behaviours focused on the interaction between teachers and students to describe the teaching and learning process through the CLT approach in the classroom. The specific actions observed included: the students' involvement in responding to the teachers' questions, the way the teacher wrote the explanations on the board, and the way she or he gave rewards to students. While observing, the first researcher (main researcher) and a co-researcher, were participant observers and they documented the classroom interactions.

After each teacher participant was observed twice following the school class schedules, he or she was interviewed face to face by the first researcher or through the telephone; it depended on the availability and convenience of the teachers for the interviews. Follow up questions were asked to generate spontaneous and rich descriptions. Prior to the semi-structured interview sessions, the first researcher contacted each teacher for an interview appointment. Each interview session was recorded with the first researcher's cell phone and lasted for about one hour. The items on the interview protocol were used to obtain deeper information on the variables inquired in the questionnaire, which were their background knowledge in teaching reading, approaches or methods in teaching reading, familiarity with the CLT approach, implementation of the CLT approach in teaching reading, evaluation on students' performance and perceptions in teaching reading.

\title{
Data Analysis
}

For the questionnaire, statistical analysis (i.e. finding the mean and standard deviation) was done to each variable. The responses were then interpreted and categorized into high, moderate and low, with high: one standard deviation above the mean, moderate: at the mean, and low: one standard deviation below the mean (Cohen, Cohen, West \& Aiken, 2003).

In analysing the data from observations and interviews, the stages proposed by Miles, Huberman and Saldaña (2014) were used: data condensation, data display, drawing and verifying conclusions. In data condensation, the researchers reduced data by selecting, focusing, simplifying, and organising them for coding, and discarding irrelevant ones. Displaying data means the use of excerpts, tables and graphs (if necessary) to help in the presentation of inferences so that the data can be better interpreted and communicated. Finally, in drawing and verifying conclusions, data was described by referring back to data display and raw data.

\section{Results of Research}

The findings from questionnaires were analysed using frequency counts and percentages for each individual item, and the overall mean score and standard deviation value for each of the variable. The overall mean score and standard deviation of each variable can be seen in Table 2. It is then followed by a description of the findings for each of the variable. This includes a triangulation of data from the questionnaires with those from the observations and interviews. 
Martin KUSTATI, Yunisrina Qismullah YUSUF, Nooreiny MAAROF. English teachers' voices on communicative language teaching for reading in Indonesian rural classrooms

\section{PROBLEMS \\ OF EDUCATION \\ IN THE $21^{\text {st }}$ CENTURY \\ Vol. 76, No. 5, 2018 \\ Table 2. The results from teachers' questionnaire.}

\begin{tabular}{llll}
\hline Variables & Mean & SD & Interpretation \\
\hline Background knowledge in teaching reading & 3.85 & 0.45 & High \\
Approaches or methods in teaching reading & 3.64 & 0.35 & Moderate \\
Student-centred method & 3.62 & 0.41 & Moderate \\
Teacher-centred methods & 3.67 & 0.40 & High \\
Familiarity with the CLT approach & 3.56 & 0.49 & Moderate \\
Implementation of the CLT approach in teaching reading & 3.87 & 0.35 & High \\
Evaluation on students' performance & 3.65 & 0.44 & Moderate \\
Perceptions in teaching reading & 3.82 & 0.37 & High \\
Total & 3.70 & 0.25 & High \\
\hline
\end{tabular}

\section{Background Knowledge in Teaching Reading}

The results in Table 2 show that the overall mean score for the teachers' background knowledge was 3.85 (high) with a standard deviation of 0.45 . This reveals that the English teachers in rural areas felt they have adequate knowledge to teach reading in English. This finding is related to the findings on the demographic data of participants, which revealed that $83.3 \%$ of them held Master's and Bachelor's degrees and 79.2\% had experiences in English language teaching from 10 to over 20 years.

The interview findings also revealed that some teachers were pro-active or at least tried to implement the CLT approach in teaching reading. For example, T8 (coded from Teacher Participant number 8) used various reading materials and teaching techniques in her classrooms. From observations in the classroom, she was comfortable with her way of teaching and had adequate knowledge to teach the subject effectively and confidently.

Thus far, the teachers received information on CLT and its implementation directly from another teacher in their school, respectively. Typically, the Department of Education in the province would give training on specific teaching methods or techniques based on the mandate from the Ministry of Education. Then, one teacher from each school in the province would be called to attend it. Later, these teachers were to pass on the new knowledge to other teachers in their schools, respectively. The teacher participants in this research, however, said that this was not enough from them to fully develop their knowledge on CLT. Despite there were more training provided by the MGMP, Musyawarah Guru Mata Pelajaran (or the Deliberation of Subject Teachers), a monthly training for teaching methodology, held by the Department of Education in the province, but not all teachers in the rural areas could regularly attend them because this training is held in the city. They were of course helpful, but to attend them was time and money constraint if their schools did not specifically give them a leave and funding to attend it. To date, participation in the MGMP trainings is voluntarily for those who have time to join them.

\section{Approaches or Methods in Teaching Reading}

The results of the overall mean score of the approaches and methods used by teachers was 3.64 (moderate) with a standard deviation of 0.35 . In this section, the questionnaire items are divided into two sub-constructs: teacher-centred and student-centred. These were inquired because CLT encouraged students to be active learners via student-centred, meanwhile traditional teaching before CLT was mostly teacher-centred. Hence, the researchers would like to know whether the knowledge and perception on CLT have more or less changed the teachers' 
teaching operations in their classrooms. The results showed that the mean score of teachercentred method was 3.67 (high) with a standard deviation of 0.40 . Meanwhile, the mean score

PROBLEMS OF EDUCATION IN THE $21^{\text {st }}$ CENTURY Vol. 76, No. 5, 2018 of the student-centred teaching method was 3.62 (moderate) with a standard deviation of 0.41 . This finding suggests that the approaches or methods used for teaching reading in rural areas in West Sumatera were more inclined toward teacher-centred.

For teachers who were tending to teacher-centred, T3, T5 and T6 acknowledged that they almost never implemented the ideas and opinion activities, because of the time constraint and their students' low English proficiency. Similarly, due to the large class, T1 avoided and discouraged the use of ideas and opinion activities in reading class and tended to implement individual work activities, reading aloud, and reading silently. T1 also informed that class size made it generally hard for most teachers to organize and monitor group activities, especially for classes with immovable chairs and desks. There were usually over forty students in one class of a typical Indonesian public school. So, T1 personally found it difficult, if not entirely impossible, to implement CLT in such large classes.

Meanwhile, teachers who were inclined to student-centred classrooms implemented various activities to stimulate the students to be dynamic in class. These activities included selecting various teaching materials to avoid boredom, asking students to share their ideas and opinion to each other, asking the students to express their ideas after reading the text, and setting cooperative tasks. The various reading materials were based on the Indonesian 2006 Curriculum syllabus and lesson plans. They were selected from books, newspapers, journals, brochures, magazines, website, and other sources which are relevant to the syllabus and lesson plans.

The interview findings suggested that the teachers' activities were focussed on making their classes more student-centred. T2 affirmed the aim of performing these activities, which was to determine the level of the students' oral performance when she interacted with the students. It means that it was easy for her to know the level of students' ability when they share their ideas and opinions. T7 explained that he implemented these activities when he wanted the students to comprehend every paragraph of the text.

From observations, about $62.5 \%$ (5) teachers allowed their students to express ideas individually and $75 \%$ (6) teachers allowed their students to express their ideas in groups (such as in group work for group presentations). But, in reality, the majority of students in the classes observed were rather passive although their English teachers (such as T3, T4, T5, T6, T7, and T8) had attempted to motivate them to speak up their ideas by creating various communicative activities in groups or pairs. This might be caused by their lack of self-confidence and proficiency. For example, in a classroom, only five to seven students who actively conveyed their ideas and opinions in English, while others were silent.

It was also noted that the teachers sometimes used visual aids in classroom learning $(29.9 \%)$ and there were those who do not $(27.1 \%)$. The interviews further revealed that only $25 \%$ (or 2) of teachers acknowledged that their students can learn reading lesson without visual aids. T2, who used visual aids, stated that he did so to assist low achieving students in learning. T4 voiced that "visual aids can assist our students in showing positive attitudes when carrying out reading tasks. It also helps them to become more active during group work. Though not fully in the English language, but everyone is discussing and talking with each other in group work". These teachers moreover explained that it was quite difficult for the students to learn reading without any guidance from their teachers, because English is a foreign language subject. Guidance from teachers was needed with visual aids to assist the process. Thus, this made teachers to be more vigorous than their students in using English in class (i.e. teacher centred). 
Martin KUSTATI, Yunisrina Qismullah YUSUF, Nooreiny MAAROF. English teachers' voices on communicative language teaching for reading in Indonesian rural classrooms

\author{
PROBLEMS \\ OF EDUCATION \\ IN THE $21^{\text {st }}$ CENTURY \\ Vol. 76, No. 5, 2018 \\ 656
}

\section{Familiarity with the CLT Approach}

The results from the questionnaire show that the overall mean score of the teachers' familiarity with CLT in teaching reading was 3.56 (moderate) with a standard deviation of 0.49 . This means that the English teachers were moderately familiar with CLT in teaching reading. Despite the statistics in the questionnaire on teachers' familiarity with the CLT approach was found to be moderate, nevertheless, only three out of the eight teachers interviewed acknowledged that they followed trainings, workshops or seminars on CLT, while others almost never followed these training programs due to their time constraints. Their responses based on the interviews revealed that there were already a few in-service programs for teachers about the CLT approach and other teaching methods and approaches, an example was the monthly MGMP. Nevertheless, not all of the teachers in the rural areas were able to attend these programs. They informed that they had reasons for not doing so. First, the trainings, workshops, and seminars schedules overlapped with their teaching hours. If they followed these activities regularly, they claimed that they would not be able to finish the syllabus and the lessons because there were only four to six English teachers in a school and each was to teach 12 hours per week. They further expressed their anticipation to their schools' management to lessen their burden on school work and administration so that they would have more time to attend the events.

For the minority of teachers who managed to attend trainings, workshops and seminars on CLT run by the MGMP, they asserted that it was very useful for improving their knowledge of current methods. Even though they also disclosed some fear of learning new methods at first because they were used to the traditional ones, nevertheless they did have curiosity to learn more about CLT. They acknowledged that the training was needed because then they could improve their knowledge on the current development of English teaching methods. This could further assist them to develop their students' communicative competence by orienting themselves to CLT more easily in their classes. They also stated that this program was important because it was an opportunity to share their syllabus, teaching methodology and other current information on language teaching. Hence, the teachers hoped that the government would provide more workshops especially for teachers residing and teaching in the rural areas.

The findings suggest that there is a shortage of training courses for EFL education in rural areas of West Sumatra. For the little training that were currently available, such as given by the MGMP, this was also a problem for the teachers to attend because of school work and administration burden, time consumption and limited funding. The literature notes that teachers with adequate pedagogical knowledge were found to represent content of teaching more accurately and to focus on the students' understanding and respond with appropriate explanations. Those who had less, relied on their background knowledge on teaching reading which they learned during their university years and teaching experiences.

\section{Implementation of CLT Approach in Teaching Reading}

The findings for this category reveal that the English language teachers in rural high schools implemented the CLT approach in teaching reading. The mean score for this variable is 3.87 (high), with a standard deviation of 0.35 . The questionnaire findings revealed that a majority of English teachers used CLT approaches in before, during and post-reading activities. The questionnaire items on the pre-teaching activities revealed these teachers did greet the students when teaching reading $(88.9 \%)$, used pictures, transparencies, and story-telling to recall the students' background knowledge when teaching reading (50.7\%), asked questions related to previous texts $(74.3 \%)$, and reminded the students of the previous lessons when teaching reading (85.4\%). During reading, they asked some questions related to the current topic when teaching reading $(88.2 \%)$. Most of these questions were in the form of $\mathrm{W}-\mathrm{H}$ by having the students to exchange each other's questions $(74.3 \%)$. Meanwhile, during the post-reading activities, teachers asked the students to summarize the text when teaching reading $(57.7 \%)$, provided students 
with various exercises that can be contextualized when teaching reading (50.8\%), and asked the students to report the summary in class when teaching reading $(50.7 \%)$. The results from the interviews and observations also indicated that forming W-H question activities was the most common teaching and learning activity carried out by all participants in the post-reading stage. Six teachers often asked their students to form W-H question based on their understanding of the reading texts, whilst the other two do not. T1 explained that this activity helped the students to express their ability and self-confidence. It was also observed that a majority of teachers usually used Indonesian when explaining the texts because only a small number of their students could understand the teachers' explanation in English.

In relation to exercises conducted in class, the questionnaire revealed that most teachers preferred to get the students to highlight the main idea of each paragraph $(86.9 \%)$, provide communicative activities (85.4\%), and create situations that encouraged students to use and work with their reading lesson (74.5\%), and mostly read aloud (90.3\%). When asked during the interview about reading aloud activities, all teachers acknowledged that they helped students to increase their self-confidence to produce and use English. T5 added that it was also an advantageous practice to improve the students' pronunciation.

Even though the questionnaire result shows that there was a high indication that English teachers in rural areas were implementing the CLT approach in teaching reading, thus is was observed that $75 \%$ (or 6 ) of the teachers asked their students to read the text and were asked to explain the text per paragraph during reading classes. These observations indicated otherwise, that most teachers implemented traditional teaching methods instead of the CLT approach.

\section{Evaluation on Students' Performance}

The result from the questionnaire shows that the overall mean score of the teachers' evaluation on students' performance in reading classes is 3.65 (moderate), with a standard deviation of 0.44 . The data from the questionnaire items show that over $70 \%$ of teachers gave written exercises which follow the format the UAS (Ujian Akhir Semester or End of the Semester Examination) or UAN exam (Ujian Akhir National or Final National Examination) and gave a brief note to enhance students' understanding on the reading text. Furthermore, quite a large proportion of teachers $(68.1 \%)$ gave individual assignment when teaching reading. Meanwhile, $68 \%$ of the teachers explained the lessons in Indonesian, where they asked students to read, then, explain the text paragraph by paragraph. About $61 \%$ of teachers seemed comfortable being the sole provider of knowledge.

The above questionnaire responses are generally consistent with the interview findings; teachers claimed evaluations were done through individual work activities as the most common teaching and learning activities carried out in the classrooms. The teachers acknowledged that they performed these activities to examine the students' reading comprehension. Another personal reason to perform the individual activities was to make it easier for the students to do narrative tasks. From observations, there were three teachers who gave individual assignments after discussing the reading text. Meanwhile, five teachers provided individual assignments as homework.

\section{Perceptions in Teaching Reading}

The results from the questionnaire showed that the mean score for this variable is 3.82 (high), with a standard deviation of 0.37 . This indicates that the English teachers have high positive perceptions in teaching reading in their classes.

Following the CLT approach, results from interviews also revealed that when starting the reading class, teachers would firstly greet students to get hold of their focus on the reading class. They acknowledged that this was an important step to be done as an effort to upsurge the students' concentration. The observation findings also showed that three teachers generally

PROBLEMS

OF EDUCATION

IN THE $21^{\text {st }}$ CENTURY

Vol. 76, No. 5, 2018

657 
Martin KUSTATI, Yunisrina Qismullah YUSUF, Nooreiny MAAROF. English teachers' voices on communicative language teaching for reading in Indonesian rural classrooms

\section{PROBLEMS \\ OF EDUCATION \\ IN THE $21^{\text {st }}$ CENTURY Vol. 76, No. 5, 2018 \\ 658}

started the class by forms of greeting, reminding the students about the previous lesson, asking questions related to previous lessons and checking their background knowledge on the current reading text. Other three teachers started the class by greeting and checking the students' background knowledge on the current texts by showing pictures and visual aids. Meanwhile, two teachers directly asked the students to open up the textbook after greeting, and read the text, and do the exercises provided afterwards.

The CLT approach encouraged pair and group work because classroom practice should mostly be student-centred. But, the results from observations revealed that only 3 teachers used pair work activities to promote collaborative learning to encourage students' involvement in reading practices. Various tasks were assigned for the pairs but not all students were actively involved in the assignments. And those who were involved in the discussion would mostly use Indonesian.

The questionnaire revealed that most teachers accepted students' view on reading text as long as they are well explained (60.4\%). About half of the teachers $(54.2 \%)$ claimed that they used role-play activities when teaching reading as suggested by the CLT approach. But, the findings from the observations and interviews, once again, contrasted with the questionnaire. It was revealed that most English teachers seldom carried out role-play activities. Only one teacher sometimes used these activities; the others preferred students' individual work so there would be quiet classrooms. These teachers said that their students' low English proficiency made communicative activities, such as role-play activities, difficult and challenging to carry out in the classroom. This implies that this activity was rarely used by teachers in the rural areas.

Furthermore, it was also found that there were only six teachers who rewarded their students with little prizes when they could perform the task well, such as giving writing utensils and notebooks. In the meantime, other teachers reasoned that to give rewards to students in the form of objects was costly compared to their income, which was deemed relatively low compared to their living cost in the country.

\section{Discussion}

Analysing the findings taken from the questionnaire, interviews, and observation, the implementation of CLT can be seen from the activities in the three-phase procedures: before, during, and post-reading stages. The findings revealed that a majority of English teachers in rural areas of West Sumatra had positive perceptions on the CLT approach. Ahmad and Rao (2013), Hu (2002) and Rao (2006) find that EFL language teachers generally agree with the main assumptions of language learning promoted in CLT. This is because in this approach, language in the classroom is used to perform meaningful tasks and learners should be provided with opportunities to engage in meaningful interactions. And so, the CLT approach for reading shows that meaning does not rely merely upon the printed words but the students bring certain knowledge experience, emotion, and culture to the reading that affects comprehension (Al-Issa, 2011; Keshavarz, Atai \& Ahmadi, 2007).

Although a majority of the teachers in this research acknowledged that they have implemented CLT activities in the questionnaire, the interview and observation results revealed otherwise. It was found that a majority of teachers still implemented traditional (teacher-centred) methods in teaching reading, and that various problems did exist, and some teachers were not able to completely implement CLT. Among the obstacles was the students' low proficiency level, where the teachers faced difficulty in stimulating the students to speak. Another cause for the teachers to be persistent with the teacher-centred approach was the large class sizes. Here, teachers found it difficult to give students individualized attention. Tight schedule is another factor that constrained the teachers. CTL activities and interactions require a lot of time which is not possible in their situation because they have a packed syllabus to follow and to accomplish. Limited training among the teachers on CLT was another factor that led the teachers to implement traditional approaches. The teachers felt powerless to fully implement CLT due to 
their inadequate knowledge of it. They felt that they needed more current in-service trainings, workshops, and seminars on CLT.

Ahmad (2008) states that teachers' previous experience and knowledge are fundamental in determining their performances. He noted that teachers felt insecure about their level of subject-matter knowledge and indicated that they need to know more subject matter before entering the classroom. Consequently, this is similar to the case with the CLT implementation by the English teachers in rural areas. Since they have less knowledge and less support to practice the approach, and so they lack the motivation and confidence to employ it in their classroom. With sufficient background knowledge and provision, the English teachers can maintain confidence to teach. Moreover, Cochran-Smith and Lytle (2001) also say that teachers usually implement their knowledge on what they know instead of what they do, bringing prior knowledge and personal experiences to bear on the new learning situations.

The English teachers in this research believed that their willingness to implement CLT and knowledge of appropriate tools can improve the classroom. However, not every teacher was willing to try as hard as the others, and not every teacher was as creative as others. Therefore, for those teachers who lack these qualities, the government, schools, or teacher preparation programs could invite other teacher trainers who have succeeded with different CLT practices to offer workshops or make short video presentations of their successful activities to these teachers. The Department of Education for West Sumatra have to make sure that access and support for these training to the rural teachers are provided. It is also suggested that these trainers should come to the rural areas to hold the trainings instead rather than having the teachers in the rural areas go to the city if time and funding are obstacles on their part. This would both address the need for more professional development and might help more teachers become willing to practice CLT.

As a final point, Holliday (1994) says that teachers are the key to the development of context-sensitive methodology. It means that teachers can easily change their values, help and bring about deeper changes if they understand why there is a need to change. Therefore, training these English teachers who teach in rural areas on CLT will further assist them in implementing the concepts and principles of this approach. They would be more ready to meet the demands of CLT as required in the curriculum and find ways to overcome any constraints in its implementation.

\section{Conclusions}

It can be concluded that the English teachers teaching in rural areas in West Sumatra had positive perceptions on the CLT approach. But a majority of them still implemented the traditional (teacher-centred) approach in teaching reading compared to the student-centred approach as suggested by CLT. Their preferred choice of teaching methods in teaching reading were influenced by several factors; namely, the students' low proficiency level, their low degree of self-confidence and motivation, large class sizes, limited teaching schedule, and the teachers' modest knowledge on CLT. This made the traditional approach to be prevalent in the rural classrooms. Teachers' domination and the use of their native language were also obvious in the implementation of instruction and teaching.

From the above conclusion, this research indicates that the teachers attempted to implement CLT; however, contextual factors had impacted its implementation. This research raises concerns that all stakeholders need to take into account when a policy to use CLT in the classroom is proclaimed by the Minister of Education. Policy cannot be successfully implemented without listening to the teachers' voices as they are the key agents of change. If the policy of learning reform is to be successful, intensive and consistent teacher development must be wellorganized, and sufficient resources must be allocated so that all schools, especially those in rural areas, can meet the objectives. 
Martin KUSTATI, Yunisrina Qismullah YUSUF, Nooreiny MAAROF. English teachers' voices on communicative language teaching for reading in Indonesian rural classrooms

\author{
PROBLEMS \\ OF EDUCATION \\ IN THE $22^{\text {st }}$ CENTURY \\ Vol. 76, No. 5, 2018 \\ 660 References
}

Achmad, D., \& Yusuf, Y. Q. (2014). Observing pair-work task in an English speaking class. International Journal of Instruction, 7 (1), 151-164.

Ahmad, F. (2008). Presage, context, process and product: Influencing variables in literature instruction in an ESL context. GEMA Online Journal of Language Studies, 8 (1), 1-21.

Ahmad, S., \& Rao, C. (2013). Applying communicative approach in teaching English as a foreign language: A case study of Pakistaner. Porta Linguarum: Revista Internacional de Didáctica de las Lenguas Extranjeras, 20, 187-203.

Al-Issa, A. (2011). Schema theory and L2 reading comprehension: Implications for teaching. Journal of College Teaching \& Learning (TLC), 3 (7), 41-48.

Ansarey, D. (2012). Communicative language teaching in EFL contexts: Teachers' attitude and perception in Bangladesh. ASA University Review, 6 (1), 61-78.

Ardianti, T. M., \& Mauludin, L. A. (2017). Students' responses on the application of Authentic Assessment in EFL reading class. Metathesis: Journal of English Language, Literature, and Teaching, 1 (2), $110-122$.

Berardo, S. A. (2006). The use of authentic materials in the teaching of reading. The Reading Matrix, 6 (2), 60-69.

Brandl, K. (2002). Integrating Internet-based reading materials into the foreign language curriculum: From teacher-to student-centered approaches. Language Learning \& Technology, 6 (3), 87-107.

Brown, H. D. (1994). Teaching by principles: An interactive approach to language pedagogy. Upper Saddle River, NJ: Prentice Hall Regents.

Brown, H. D. (2002). English language teaching in the "Post-Method" era: Toward better diagnosis, treatment, and assessment. In J. C. Richards, \& W. A. Renandya (Eds.), Methodology on language teaching: An anthology of current practice (pp. 9-17). Cambridge: Cambridge University Press.

Chen, H-C., Chern, C-L., \& Wu, A. M. C. (2016). Becoming reflective readers: A case study of group discussion in reading. English Teaching \& Learning, 40 (1), 1-24.

Cochran-Smith, M., \& Lytle, S. L. (2001). Beyond certainty: Taking an inquiry stance. In A. Lieberman \& L. Miller (Eds.), Teachers caught in the action: Professional development that matters (pp. 45-58). New York, NY: Teachers College Press.

Cohen, J., Cohen, P., West, S. G., \& Aiken, L. S. (2003). Applied multiple regression/correlation analysis for the behavioral sciences (3rd Ed.). Mahwah, NJ: Erlbaum.

Creswell, J. W. (2015). A concise introduction to mixed methods research. Thousand Oaks, CA: SAGE Publications, Inc.

Djiwandono, M. S. (2015). English language teacher education: Rewriting S-1 national curriculum. TEFLIN Journal, 10 (1), 17-30.

Erdiana, N., Kasim, U., \& Juwita, N. (2017). QAR Strategy implementation for reading comprehension of recount texts. Studies in English Language and Education, 4 (2), 247-256.

Firman, H., \& Tola, B. (2008). The future of schooling in Indonesia. Journal of International Cooperation in Education, 11 (1), 71-84.

Gani, S. A., Yusuf, Y. Q., \& Susiani, R. (2016). Progressive outcomes of collaborative strategic reading to EFL learners. Kasetsart Journal of Social Sciences, 37, 144-149.

Gay, L. R., \& Airasian, P. W. (2000). Educational research: Competencies for analysis and application. Upper Saddle River, NJ: Merrill.

Hampel, R., \& Hauck, M. (2004). Towards an effective use of audio conferencing in distance language courses. Language Learning \& Technology, 8 (1), 66-82.

Hamp-Lyons, L. (2000). Social, professional and individual responsibility in language testing. System, 28 (4), 579-591.

Hinkel, E. (2006). Current perspectives on teaching the four skills. TESOL Quarterly, 40 (1), 109-131.

Holliday, A. (1994). Appropriate methodology and social context. Cambridge: Cambridge University Press.

Hu, G. (2002). Potential cultural resistance to pedagogical imports: The case of communicative language teaching in China. Language Culture and Curriculum, 15 (2), 93-105.

Huda, N. (1997). A national strategy in achieving English communication ability: Globalization perspectives. Jurnal Ilmu Pendidikan, 4 (Special Edition), 281-292. 
Martin KUSTATI, Yunisrina Qismullah YUSUF, Nooreiny MAAROF. English teachers' voices on communicative language teaching for reading in Indonesian rural classrooms

Jackson, S. L. (2010). Research methods: A modular approach. Belmont, CA: Wadsworth.

Jacobs, G. M., \& Farrell, T. S. (2003). Understanding and implementing the CLT (Communicative Language Teaching) paradigm. RELC Journal, 34 (1), 5-30.

Johnson, R. B., \& Onwuegbuzie, A. J. (2004). Mixed methods research: A research paradigm whose time has come. Educational Researcher, 33 (7), 14-26.

Jubani, A., Lama, I. N., \& Gjokutaj, M. (2012). Improving the quality of learning by increasing the students' reading skills. Problems of Education in the $21^{\text {st }}$ Century, 42, 50-62.

Keshavarz, M. H., Atai, M. R., \& Ahmadi, H. (2007). Content schemata, linguistic simplification, and EFL readers' comprehension and recall. Reading in a Foreign Language, 19 (1), 19.

Koosha, M., \& Yakhabi, M. (2012). Problems associated with the use of communicative language teaching in EFL contexts and possible solutions. International Journal of Foreign Language Teaching and Research, 1 (2), 63-76.

Kromidha, E., \& Tabaku, E. (2011). Improvement of foreign language teacher education in Albania. Problems of Education in the 21st Century, 38, 50-60.

Kustati, M. (2013). The shifting paradigms in the implementation of CLT in Southeast Asia countries. Al-Ta'lim Journal, 20 (1), 267-277.

Kvale, S. (1996). Interviews: An introduction to qualitative research interviewing. Thousand Oaks, CA: Sage.

Lewis, R. (1996). Indonesian students' learning styles. EA Journal, 14 (2), 27-32.

Miles, M. B., Huberman, A. M., \& Saldaña, J. (2014). Qualitative data analysis: A methods sourcebook. Los Angeles: Sage.

Musthafa. B. (2001). Communicative Language Teaching in Indonesia: Issues of theoretical assumptions and challenges in classroom practice. Journal of Southeast Asian Education, 2 (2), 296-308.

Neuman, W. L. (2000). Social research methods: Qualitative and quantitative approaches (4th Ed.). Needham Heights, MA: Allyn and Bacon.

Nur, C. (2003). English Language Teaching in Indonesia: changing policies and practical constraints. In W. K. Ho \& R. Y. L. Wong (Eds.), English language teaching in East Asia today: Changing policies and practices (pp. 163-172). Singapore: Eastern Universities Press.

Rao, Z. (2006). Understanding Chinese students' use of language learning strategies from cultural and educational perspectives. Journal of Multilingual and Multicultural Development, 27 (6), 491-508.

Richards, J. C. (2005). Communicative language teaching today. Singapore: SEAMEO Regional Language Centre.

Richards, J. C., \& Rodgers, T. S. (2000). Approaches and methods in language teaching. Cambridge: Cambridge University Press.

Rodgers, T. S. (2001). Language teaching methodology. Retrieved from http://files.eric.ed.gov/fulltext/ ED459628.pdf.

Thompson, G. (1996). Some misconceptions about communicative language teaching. English Language Teaching Journal, 50 (1), 9-15.

Yusuf, S. B., Nasir, C., \& Rohiman, C. L. N. (2018). Using the think aloud method in teaching reading comprehension. Studies in English Language and Education, 5 (1), 148-158.

Yusuf, Y. Q., Natsir, Y., \& Hanum, L. (2015). A teacher's experience in teaching with student teams achievement division (STAD) technique. International Journal of Instruction, 8 (2), 99-112.

Yusuf, Y. Q, Fajrina, D., \& Sari, I. (2016). Developing the EFL students' reading comprehension by employing Herringbone Technique. Al-Ta'lim Journal, 23 (3), 183-190.

Zangoei, A., \& Derakhshan, A. (2014). The relationship between EFL teachers' preferences of corrective feedback and their attitudes towards Communicative Language Teaching. International Journal of Applied Linguistics \& English Literature, 3 (5), 82-90.

Received: June 25, 2018

Accepted: September 22, 2018

PROBLEMS

OF EDUCATION

IN THE $21^{\text {st }}$ CENTURY

Vol. 76, No. 5, 2018

661 
Martin KUSTATI, Yunisrina Qismullah YUSUF, Nooreiny MAAROF. English teachers' voices on communicative language teaching for reading in Indonesian rural classrooms

OF EDUCATIO

IN THE $21^{\text {st }}$ CENTURY

Vol. 76, No. 5, 2018

.

Martin Kustati

Yunisrina Qismullah Yusuf (Corresponding author)
PhD, Senior Lecturer, Imam Bonjol State Islamic University, Jln. Prof. Mahmud Yunus Lubuk Lintah, Anduring, Kuranji, Kota Padang, Sumatera Barat 25153 , Indonesia.

E-mail: martinkustati@yahoo.com

Website: https://scholar.google.com/citations?user=ZjqIIfMAAAAJ\&hl=en

PhD, Senior Lecturer, Syiah Kuala University, Jln. Teuku Nyak Arief, Darussalam, Banda Aceh 23111, Indonesia.

E-mail: yunisrina.q.yusuf@unsyiah.ac.id

Website: http://fsd.unsyiah.ac.id/yunisrina.q.yusuf/

Nooreiny Maarof
PhD, Professor, National University of Malaysia, 43600 UKM Bangi, Selangor, Malaysia.

E-mail: nooreiny@ukm.edu.my

Website: https://ukm.pure.elsevier.com/en/persons/nooreiny-maarof 